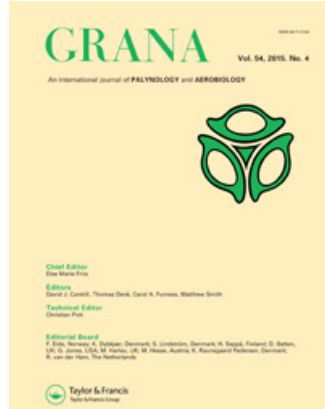

Grana

ISSN: 0017-3134 (Print) 1651-2049 (Online) Journal homepage: http://www.tandfonline.com/loi/sgra20

\title{
A melissopalynological analysis of Apis mellifera L. loads of dried bee pollen in the southern Brazilian macro-region
}

\author{
Alex da Silva de Freitas, José Augusto Gasparotto Sattler, Bianca Rodrigues \\ de Souza, Ligia Bicudo Almeida-Muradian, Aroni Sattler \& Ortrud Monika \\ Barth
}

To cite this article: Alex da Silva de Freitas, José Augusto Gasparotto Sattler, Bianca Rodrigues de Souza, Ligia Bicudo Almeida-Muradian, Aroni Sattler \& Ortrud Monika Barth (2015) A melissopalynological analysis of Apis mellifera L. loads of dried bee pollen in the southern Brazilian macro-region, Grana, 54:4, 305-312, DOI: 10.1080/00173134.2015.1096954

To link to this article: http://dx.doi.org/10.1080/00173134.2015.1096954

曲 Published online: 04 Nov 2015.

Submit your article to this journal $\pi$

Џ Article views: 89

Q View related articles $\sqsubset$

View Crossmark data ¿ 


\title{
A melissopalynological analysis of Apis mellifera $\mathrm{L}$. loads of dried bee pollen in the southern Brazilian macro-region
}

\author{
ALEX DA SILVA DE FREITAS ${ }^{1,2}$, JOSÉ AUGUSTO GASPAROTTO SATTLER ${ }^{3}$, BIANCA \\ RODRIGUES DE SOUZA ${ }^{3}$, LIGIA BICUDO ALMEIDA-MURADIAN ${ }^{3}$, ARONI SATTLER ${ }^{4}$ \\ \& ORTRUD MONIKA BARTH ${ }^{1}$
}

${ }^{1}$ Instituto Oswaldo Cruz, Fundação Oswaldo, Rio de Faneiro, Brazil, ${ }^{2}$ Departamento de Geologia, Instituto de Geociências,
Universidade Federal Fluminense, Niterói, Brazil, ${ }^{3}$ Faculdade de Ciências Farmacêuticas, Departamento de Alimentos e
Nutrição Experimental, Universidade de São Paulo, São Paulo, Brazil, ${ }^{4}$ Faculdade de Agronomia, Departamento de
Fitossanidade, Universidade Federal do Rio Grande do Sul, Porto Alegre, Brazil

\begin{abstract}
Sixty-one samples of dried bee pollen collected from various apiaries in the southern Brazilian macro-region were examined to detect the botanical origin of the pollen and to enable more accurate product certification. The palynological analysis of the samples followed the standard methodology and was conducted without the use of acetolysis. The samples were washed once or twice with ethanol and then with water. The sediment obtained was homogenised in a water/glycerine solution for microscopic observation. The target number of pollen grains to be counted was 500 pollen grains or more per sample. The results demonstrated that 35 samples consisted of a unique pollen type representing more than $90 \%$ of the pollen sum (or more than $60 \%$ if no accessory pollen was present). These samples were considered monofloral. Several pollen types grouped in a sample were related to heterofloral pollen batches. The most frequent pollen types were of Mimosa scabrella, Eucalyptus, Andira, Machaerium, Myrcia and Piptocarpha. The results of the current study were related to the surrounding vegetation of the apiaries and reflected the resources available to the bees. Furthermore, these results are relevant to apicultural activities and are commercially significant.
\end{abstract}

Keywords: Apis, palynology, pollen loads, southern Brazil, vegetation

Bees provide pollination services to plants and receive food in exchange. This relationship is reflected by the honey produced in the hive, as the honey contains evidence of the plants visited, namely, pollen found in the honey. For this reason, the analysis of pollen provides a powerful tool for determining the plants that the bees are visiting (Pirani \& Cortopassi-Laurino 1993).

The Brazilian flora is geographically diverse and is divided into five distinct macro-regions (north, northeast, midwest, southeast and south). The southern region has a tropical to subtropical climate with vegetation formations classified as ombrophilous forest, field vegetation ('Cerrado'), and 'Restinga' (Veloso 1962). A small occurrence of 'Cerrado' is limited to western Paraná (Pinha \& Siminski 2011).

Paraná is a transitional region in southern Brazil. It is located between the tropical and subtropical regions. The vegetation formations found in this state range from areas of mangroves through areas of salty marshes and ombrophilous forests. The most representative plant families are Myrtaceae, Myrsinaceae, Lauraceae, Euphorbiaceae, Asteraceae, Melastomataceae, Araceae and Arecaceae (Troppmair 1990). Other species present in the 'Cerrado' areas include: Myrsine umbellata L., Myrcengenia alpigena O.Berg, Ouratea spectabilis (Mart.) Engl., Plenckia populnea Reissek, Erythroxylum suberosum A.St.-Hil., Copaifera langsdorffi Desf., Calyptranthes concinna DC. and Myrciaria cuspidate O.Berg

Correspondence: Alex da Silva de Freitas, Departamento de Geologia, Instituto de Geociências, Universidade Federal Fluminense, Niterói, Brazil. E-mail: alexsilfre@gmail.com 


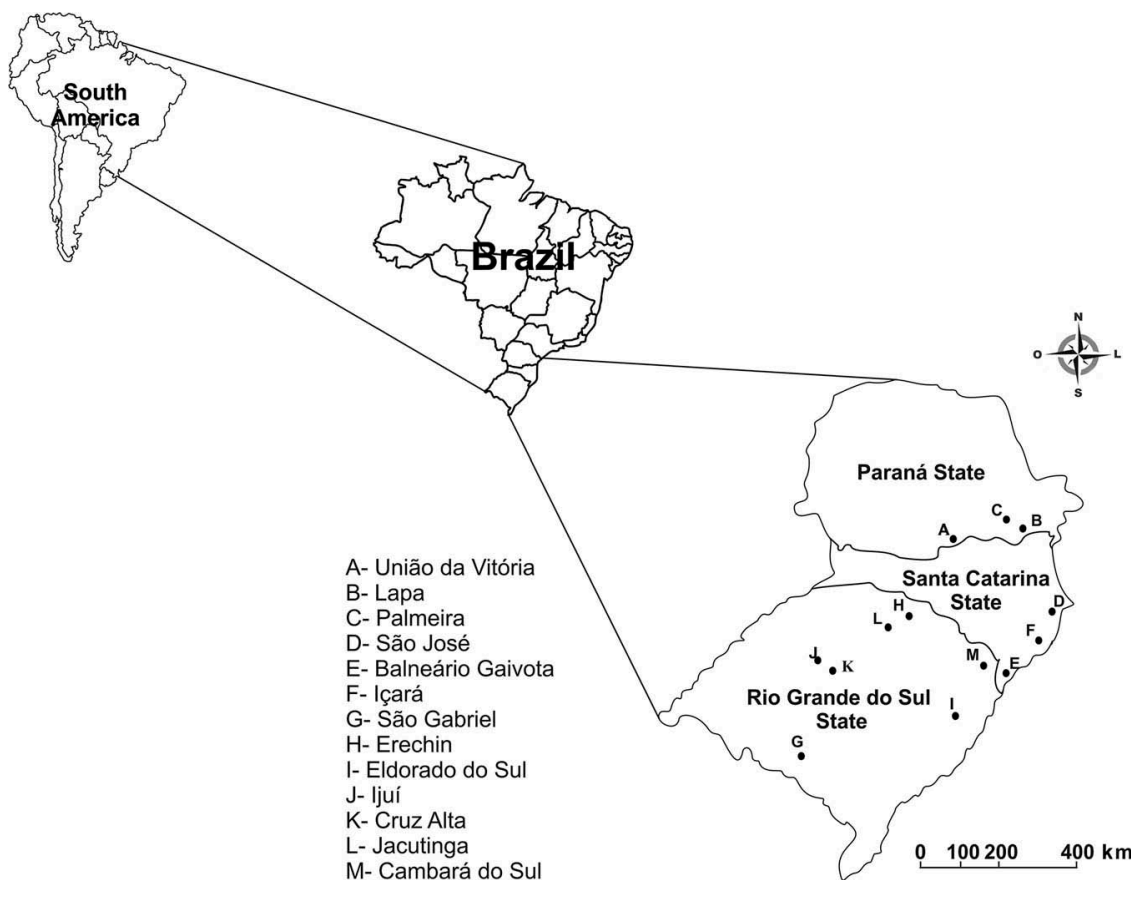

Figure 1. Map of the Southern Brazilian Region with the locations of sample collection sites. and are considered representative in this vegetation formation (Carmo et al. 2012).

In Santa Catarina, ombrophilous forests and a strong presence of Araucaria angustifolia Juss. forest are characteristic and are found throughout the state (Negrelle \& Silva 1992). Other plant families that stand out by virtue of their species richness are (especially) Asteraceae and, in addition, Myrtaceae, Fabaceae, Solanaceae, Melastomataceae, Lauraceae, Orchidaceae, Rubiaceae, Poaceae, Cyperaceae and Piperaceae (Gasper et al. 2013). The vegetation of Rio Grande do Sul consists of ombrophilous forests and a large area of Savannah (Pinha \& Siminski 2011). The most representative arboreal families are Myrtaceae, Fabaceae, Lauraceae and Euphorbiaceae (Grings \& Brack 2009). Other families with high species richness in the 'Restinga' formation are Asteraceae, Poaceae, Fabaceae, Cyperaceae and Myrtaceae (Jacobi et al. 2013). Each of these vegetation communities has a typical flowering period. Large areas in this region are used for crop production and Apis mellifera L. is increasingly used to provide pollination services (Rosa et al. 2011).

Pollen grains are collected in the corbicula of the hind legs of the bees during field activity and are stored in hive cells, where they exist as 'bee bread' (Luz \& Barth 2012). Apis mellifera, as well as other bee species and other insects, use pollen grains as their main resource for proteins and lipids. These products are required by the bee larvae and are essential to the normal growth and development of colonies (Marchini et al. 2006).
The Brazilian apiculture market is not only interested in the pollination of crop plants. Brazil's largescale agricultural production is expanding on a broad front in response to the increased demands for exports in recent years. Currently, the favourable consumer market for natural products that can serve as diet supplements or furnish therapeutic benefits has been encouraging and promoting beekeeping activity (Barreto et al. 2005). To obtain quality control of bee pollen, the botanical origin of the pollen grains must be investigated. Palynological analysis is used to identify the morphological characteristics of pollen grains (Barth 1989; Luz et al. 2007). Almeida-Muradian et al. (2005) have emphasised the importance of physicochemical analyses of bee pollen loads in improving quality control.

Melissopalynological analysis serves to enhance current knowledge of the botanical origin of pollen loads. For example, recent investigations by Santos (2011) in the Brazilian northeast region, in the southeast by Luz et al. (2010), and in the south by Freitas et al. (2013) have examined Apis mellifera pollen loads. However, there is little information about bee pollen loads from southern Brazil.

According to Falkenberg and Simões (2011), who conducted a preliminary botanical survey of southern Brazilian vegetation, Piptocarpha angustifolia Dusén ex Malme, $P$. tomentosa Baker, Baccharis uncinella DC., $B$. dracunculifolia DC., Mimosa scabrella Benth. and Vernonanthura spp. are prominent pioneering small tree and brush species occurring in early or middle successional stages. Eventually, they are also found in advanced 
Table I. Pollen types identified in the pollen batches samples collected by Apis mellifera in the Paraná State.

\begin{tabular}{|c|c|c|c|}
\hline $\begin{array}{l}\text { Municipality/GPS } \\
\text { coordinates }\end{array}$ & $\begin{array}{l}\text { Collection } \\
\text { period }\end{array}$ & Palynologycal evaluation & Predominant botanical origin \\
\hline $\begin{array}{l}\text { União da Vitória (1) } \\
26^{\circ} 10^{\prime} 38.80^{\prime \prime} \mathrm{S} \\
51^{\circ} 05^{\prime} 46.30^{\prime \prime} \mathrm{W}\end{array}$ & Spring 2011 & $\begin{array}{l}\text { PP: Machaerium (49.9\%); PA: Eucalyptus } \\
\text { (26.9\%); PI: Phoradendron (5.8\%); Senecio } \\
(13.4 \%)\end{array}$ & $\begin{array}{l}\text { Heterofloral sample with with primary } \\
\text { contributions from Machaerium and } \\
\text { Eucalyptus }\end{array}$ \\
\hline $\begin{array}{l}\text { União da Vitória (2) } \\
26^{\circ} 10^{\prime} 38.80^{\prime \prime} \mathrm{S} \\
51^{\circ} 05^{\prime} 46.30^{\prime \prime} \mathrm{W}\end{array}$ & Spring 2011 & $\begin{array}{l}\text { PP: Piptocarpha }(72.0 \%) \text {; PI: Eucalyptus } \\
\quad(9.0 \%) \text {; Crotalaria }(13.6 \%)\end{array}$ & Monofloral sample from Piptocarpha \\
\hline $\begin{array}{l}\text { União da Vitória (3) } \\
26^{\circ} 10^{\prime} 38.80^{\prime \prime} \mathrm{S} \\
51^{\circ} 05^{\prime} 46.30^{\prime \prime} \mathrm{W}\end{array}$ & Spring 2011 & $\begin{array}{l}\text { PP: Machaerium (62.1\%); PI: Eucalyptus } \\
\quad(14.6 \%) \text {; Rosaceae (5.6\%); Ilex (7.4\%); }\end{array}$ & Monofloral sample from Machaerium \\
\hline $\begin{array}{l}\text { União da Vitória (4) } \\
26^{\circ} 10^{\prime} 38.80^{\prime \prime} \mathrm{S} \\
51^{\circ} 05^{\prime} 46.30^{\prime \prime} \mathrm{W}\end{array}$ & Spring 2011 & $\begin{array}{l}\text { PP: Machaerium (65.8\%); PA: Eucalyptus } \\
\quad(21.8 \%) \text {; Ilex }(7.1 \%)\end{array}$ & $\begin{array}{l}\text { Heterofloral sample with primary } \\
\text { contributions from Machaerium and } \\
\text { Eucalyptus }\end{array}$ \\
\hline $\begin{array}{l}\text { Lapa } \\
25^{\circ} 48^{\prime} 50.27^{\prime \prime} \mathrm{S} \\
49^{\circ} 46^{\prime} 48.27^{\prime \prime} \mathrm{W}\end{array}$ & Spring 2011 & $\begin{array}{l}\text { PP: Eucalyptus (83.9\%); PI: Machaerium } \\
\quad(5.1 \%)\end{array}$ & Monofloral sample from Eucalyptus \\
\hline $\begin{array}{l}\text { Palmeira } \\
25^{\circ} 41^{\prime} 12.58^{\prime \prime} \mathrm{S} \\
50^{\circ} 09^{\prime} 32.56^{\prime \prime} \mathrm{W}\end{array}$ & Spring 2011 & $\begin{array}{l}\text { PA: Euterpe (38\%); Ilex (23.9\%); Celtis } \\
\quad(22.6 \%)\end{array}$ & $\begin{array}{l}\text { Heterofloral sample with primary } \\
\text { contributions from Euterpe, Ilex and } \\
\text { Celtis }\end{array}$ \\
\hline
\end{tabular}

stages of succession at forest edges and in clearings within the remaining forest fragments. A substantial concentration of individuals and massive flowering characterise these populations. In addition, arboreal species such as Syagrus romanzoffiana (Cham.) Glassman, Casearia sylvestris Sw., Campomanesia xanthocarpa O.Berg, Mimosa bimucronata (DC.) Kuntze, Schinus terebinthifolius Raddi, Luhea divaricata Mart. and Cupania vernalis Cambess, the sub-shrubs Senecio brasiliensis Less., Solidago chilensis Meyen and Cyrtocymura scorpioides (Lam.) Pers. and the herbaceous Paspalum notatum Flüggé are also common. Senecio brasiliensis and Solidago chilensis are typical of the 'Cerrado' vegetation and occur in countryside weed vegetation, along roadsides and in open areas (Falkenberg \& Simões 2011).

The present study aims to investigate the botanical and geographical origin of bee pollen collected in the southern Brazilian macro-region to provide results that will help to improve the certification of apicultural products that are associated with the use of this pollen by the bees.

\section{Material and methods}

A total of 61 dried pollen load samples of Apis mellifera were collected with pollen traps in 14 municipalities in southern Brazil (Figure 1) in the years 2011 and 2012. Samples from Eldorado do Sul were collected in 2014. All samples were analysed using the standard pollen analysis methodology proposed by Barth et al. (2010). Two grammes of each wellmixed sample of dried bee pollen was homogenised by stirring in $70 \%$ ethanol. Centrifuge tubes were filled to $13 \mathrm{ml}$, and the material was allowed to stand for 30 minutes or overnight. Each sample was then sonicated for five minutes to dissociate pollen grain agglomerates. After centrifugation, the samples containing a large amount of oil were subjected twice to ethanol extraction. The resulting sediment was diluted in a 1:1 mixture of water/glycerine for $30 \mathrm{~min}$ utes. One drop of this well-homogenised pollen grain suspension was applied to a microscope slide, covered with a $22 \mathrm{~mm} \times 22 \mathrm{~mm}$ cover glass and sealed with nail varnish. The stock pollen suspension was kept for a long time in glycerine at room temperature in Eppendorf vials. Two microscope slides were prepared, and more than 500 pollen grains of each sample were counted. Samples were observed using light and polarised light microscopy.

The pollen classes used in this study followed the classification given in Barth et al. (2010): meaning PP (predominant pollen present at a frequency of more than $90 \%$, or a frequency of more than $60 \%$ if no accessory pollen was present), AP (accessory pollen, 15-45\%) and IP (important pollen, 3-15\%). These classes were used for qualitative and quantitative analyses. Samples were classified as monofloral or heterofloral batches according to their pollen grain percentages. Pollen grain illustrations presented in Barth (1989), Roubik and Moreno (1991) and Moreti et al. (2002) were used for pollen identification. Micrographs of non-acetolysed pollen grains were obtained with a digital camera at $400 \times$ magnification. 
Table II. Pollen types identified in the pollen batches samples collected by Apis mellifera in the Santa Catarina State.

\begin{tabular}{|c|c|c|c|}
\hline $\begin{array}{l}\text { Municipalities/GPS } \\
\text { coordinates }\end{array}$ & $\begin{array}{l}\text { Collection } \\
\text { period }\end{array}$ & Palynologycal evaluation & Predominant botanical origin \\
\hline $\begin{array}{l}\text { São José } \\
27^{\circ} 34^{\prime} 00.35^{\prime \prime} \mathrm{S} \\
48^{\circ} 43^{\prime} 18.27^{\prime \prime} \mathrm{W}\end{array}$ & Spring 2011 & $\begin{array}{l}\text { PA: Euterpe (32.6\%); Eupatorium (16.1\%); PI: } \\
\text { Machaerium (10.2\%); Piper (14.7\%); Eucalyptus } \\
\quad(15.0 \%) \text {; Senecio }(3.9 \%) \text { Ilex }(4.5 \%)\end{array}$ & $\begin{array}{l}\text { Heterofloral sample with primary } \\
\text { contributions from Euterpe and } \\
\text { Eupatorium }\end{array}$ \\
\hline $\begin{array}{l}\text { São José } \\
27^{\circ} 34^{\prime} 00.35^{\prime \prime} \mathrm{S} \\
48^{\circ} 43^{\prime} 18.27^{\prime \prime} \mathrm{W}\end{array}$ & Spring 2011 & $\begin{array}{l}\text { PA: Euterpe }(38.0 \%) \text {; Ilex }(23.9 \%) \text {; Celtis }(22.6 \%) \text {; } \\
\text { PI: Eucalyptus }(13.0 \%)\end{array}$ & $\begin{array}{l}\text { Heterofloral sample with primary } \\
\text { contributions from Euterpe and Ilex }\end{array}$ \\
\hline $\begin{array}{l}\text { São José } \\
27^{\circ} 34^{\prime} 00.35^{\prime \prime} \mathrm{S} \\
48^{\circ} 43^{\prime} 18.27^{\prime \prime} \mathrm{W}\end{array}$ & Spring 2011 & $\begin{array}{l}\text { PA: Poaceae }(31.4 \%) \text {; Eucalyptus }(20.9 \%) \\
\text { Melastomataceae }(25.6 \%) \text {; PI: Euterpe }(10.1 \%) \text {; } \\
\text { Piper }(6.3 \%)\end{array}$ & $\begin{array}{l}\text { Heterofloral sample with primary } \\
\text { contributions from Poaceae, } \\
\text { Eucalyptus and Melastomataceae }\end{array}$ \\
\hline $\begin{array}{l}\text { Balneário Gaivota } \\
29^{\circ} 09^{\prime} 25.2^{\prime \prime} \mathrm{S} \\
49^{\circ} 34^{\prime} 51.2^{\prime \prime} \mathrm{W}\end{array}$ & Spring 2011 & $\begin{array}{l}\text { PA: Montanoa }(21.2 \%) ; \text { Lithraea }(31.8 \%) ; \\
\quad \text { Eucalyptus }(22.2 \%) ; \text { Undetermined }(17.0 \%)\end{array}$ & $\begin{array}{l}\text { Heterofloral sample with primary } \\
\text { contributions from Montanoa, } \\
\text { Lithraea and Eucalyptus }\end{array}$ \\
\hline $\begin{array}{l}\text { Içara } \\
28^{\circ} 43^{\prime} 37.7^{\prime \prime} \mathrm{S} \\
49^{\circ} 18^{\prime} 52.4^{\prime \prime} \mathrm{W}\end{array}$ & Winter 2011 & $\begin{array}{l}\text { PP: Brassica }(77.3 \%) \text {; PA: Asteraceae }(15.8 \%) \text {; } \\
\quad \text { Eucalyptus }(6.3 \%)\end{array}$ & $\begin{array}{l}\text { Heterofloral sample with primary } \\
\text { contributions from Brassica and } \\
\text { Asteraceae }\end{array}$ \\
\hline
\end{tabular}

\section{Results}

The samples of dried pollen loads were first grouped according to the southern Brazilian states in which the samples were collected (Tables I-III).

\section{Paraná (Table I)}

Two samples from the União da Vitória municipality showed predominant pollen types of Piptocarpha (Asteraceae) and Machaerium (Fabaceae, Faboideae). Eucalyptus (Myrtaceae) pollen occurred in several samples $(n=5)$ and was predominant only in the sample from Lapa municipality. No predominant pollen type was detected in the sample from Palmeira municipality, where a large contribution of Euterpe (Arecaceae), Ilex (Aquifoliaceae) and Celtis (Ulmaceae) pollen types was observed.

\section{Santa Catarina (Table II)}

All samples were considered heterofloral and contained Eucalyptus pollen grains. The four samples from São José municipality all contained the Euterpe pollen type. The Ilex type occurred in two samples along with a large representation of Celtis, Eupatorium (Asteraceae), Melastomataceae, Piper (Piperaceae) and Poaceae. A different pollen spectrum was found in the other two municipalities. A strong contribution of Lithraea (Anacardiaceae) and Montanoa (Asteraceae) was observed in the Balneário Gaivota sample. However, in the Içara municipality, Brassica napus L. (Brassicaceae) was predominant along with a presence of Asteraceae pollen grains.

\section{Rio Grande do Sul (Table III)}

This state had the highest number of samples analysed $(n=49)$. Thirty samples were considered monofloral. Eucalyptus pollen was found in the majority of samples $(n=41)$, followed by Poaceae $(n=11)$, Myrcia $(n=6)$, Brassica napus $(n=6)$ and Mimosa scabrella (Mimosaceae) $(n=5)$. One monofloral sample of Brassica napus (São Gabriel 2) only occurred in the São Gabriel municipality. This pollen type was found in two other samples (São Gabriel 1 and 2), where it was associated with several pollen types. Eucalyptus pollen was present in all four analysed samples. Erechim municipality had a high contribution of Eucalyptus and the Dalbergia pollen type. The Andira (Fabaceae) pollen type represented $98.5 \%$ of the pollen content and yielded a monofloral sample in the Ijuí municipality.

The samples from Cruz Alta municipality contained one monofloral sample of Eucalyptus pollen. The other two samples consisted of either the Eucalyptus or Brassica napus pollen type, with variable percentages (Cruz Alta 2 and 3). No monofloral samples were present in the Jacutinga municipality. Heterofloral samples contained large contributions of Melastomataceae, Myrcia and Piper pollen types. Cambará do Sul municipality had monofloral samples of the Mimosa scabrella pollen type in four pollen batches (Cambará do Sul 1-4). Eucalyptus pollen was present in one batch (Cambará do Sul 6). The Cambará do Sul 5 sample had a large contribution of Ilex and Asteraceae pollen grains. The Cambará do Sul 7 sample contained large amounts of Eucalyptus and of the Eupatorium pollen type. The other sample (Cambará do Sul 8) had a high representation of Ilex and Mimosa scabrella pollen grains. 
Table III. Pollen types identified in pollen batches collected by Apis mellifera in the Rio Grande do Sul State and botanical evaluation.

\begin{tabular}{|c|c|c|c|}
\hline $\begin{array}{l}\text { Municipalities/GPS } \\
\text { coordinates }\end{array}$ & $\begin{array}{l}\text { Collection } \\
\text { period }\end{array}$ & Palynological evaluation & Predominant botanical origin \\
\hline $\begin{array}{l}\text { São Gabriel (1) } \\
30^{\circ} 15^{\prime} 27.72^{\prime \prime} \mathrm{S} \\
54^{\circ} 28^{\prime} 59.41^{\prime \prime} \mathrm{W}\end{array}$ & Winter 2011 & $\begin{array}{l}\text { PP: Brassica }(80.5 \%) \\
\text { PA: Eucalyptus }(19.4 \%)\end{array}$ & $\begin{array}{l}\text { Heterofloral sample with primary } \\
\text { contribution of Brassica and } \\
\text { Eucalyptus }\end{array}$ \\
\hline $\begin{array}{l}\text { São Gabriel (2) } \\
30^{\circ} 15^{\prime} 27.72^{\prime \prime} \mathrm{S} \\
54^{\circ} 28^{\prime} 59.41^{\prime \prime} \mathrm{W}\end{array}$ & Winter 2011 & $\begin{array}{l}\text { PP: Brassica }(84.6 \%) \\
\text { PI: Eucalyptus }(9.2 \%) \text {; Machaerium }(5.2 \%)\end{array}$ & Monofloral sample of Brassica \\
\hline $\begin{array}{l}\text { São Gabriel (3) } \\
30^{\circ} 15^{\prime} 27.72^{\prime \prime} \mathrm{S} \\
54^{\circ} 28^{\prime} 59.41^{\prime \prime} \mathrm{W}\end{array}$ & Winter 2011 & $\begin{array}{l}\text { PP: Brassica }(48.5 \%) \\
\text { PA: Machaerium }(16.6 \%) \text {; Eucalyptus }(16.4 \%) \\
\text { PI: Caryca }(13.3 \%) ; \text { Psychotria }(4.7 \%)\end{array}$ & $\begin{array}{l}\text { Heterofloral sample with primary } \\
\text { contribution of Brassica, Machaerium } \\
\text { and Eucalyptus }\end{array}$ \\
\hline $\begin{array}{l}\text { São Gabriel (4) } \\
30^{\circ} 15^{\prime} 27.72^{\prime \prime} \mathrm{S} \\
54^{\circ} 28^{\prime} 59.41^{\prime \prime} \mathrm{W}\end{array}$ & Spring 2011 & $\begin{array}{l}\text { PP: Caesalpiniaceae }(56.1 \%) \\
\text { PA: Eucalyptus }(32.3 \%)\end{array}$ & $\begin{array}{l}\text { Heterofloral sample with primary } \\
\text { contribution of a Caesalpiniaceae and } \\
\text { Eucalyptus }\end{array}$ \\
\hline $\begin{array}{l}\text { Erechim } \\
27^{\circ} 37^{\prime} 17.05^{\prime \prime} \mathrm{S} \\
52^{\circ} 15^{\prime} 28.91^{\prime \prime} \mathrm{W}\end{array}$ & Spring 2011 & $\begin{array}{l}\text { PP: Eucalyptus }(70.6 \%) \\
\text { PA: Dalbergia }(16.4 \%) \\
\text { PI: Lithraea }(10.5 \%)\end{array}$ & $\begin{array}{l}\text { Heterofloral sample with primary } \\
\text { contribution of Eucalyptus and } \\
\text { Dalbergia }\end{array}$ \\
\hline $\begin{array}{l}\text { Ijuí } \\
28^{\circ} 21^{\prime} 41.14^{\prime \prime} \mathrm{S} \\
53^{\circ} 50^{\prime} 34.84^{\prime \prime} \mathrm{W}\end{array}$ & Spring 2011 & PP: Andira (98.5\%) & Monofloral sample of Andira \\
\hline $\begin{array}{l}\text { Cruz Alta (1) } \\
28^{\circ} 37^{\prime} 35.94^{\prime \prime} \mathrm{S} \\
53^{\circ} 37^{\prime} 57.66^{\prime \prime} \mathrm{W}\end{array}$ & Spring 2011 & $\begin{array}{l}\text { PP: Eucalyptus }(83.9 \%) \\
\text { PI: Machaerium }(5.1 \%) \text {; Brassica napus }(6.0 \%)\end{array}$ & Monofloral sample of Eucalyptus \\
\hline $\begin{array}{l}\text { Cruz Alta (2) } \\
28^{\circ} 37^{\prime} 35.94^{\prime \prime} \mathrm{S} \\
53^{\circ} 37^{\prime} 57.66^{\prime \prime} \mathrm{W}\end{array}$ & Spring 2011 & $\begin{array}{l}\text { PA: Eucalyptus }(21.8 \%) \text {; Euterpe }(16.0 \%) \\
\text { PI: Machaerium }(13.1 \%) \text {; Brassica napus }(12.3 \%) \text {; } \\
\quad \text { Borreria }(5.3 \%) ; \text { Asteraceae }(4.8 \%) ; \text { Protium } \\
\quad(4.4 \%) ; \text { Tapirira }(3.8 \%) \text {; Phrygilanthus }(3.5 \%)\end{array}$ & $\begin{array}{l}\text { Heterofloral sample with primary } \\
\text { contribution of Eucalyptus and } \\
\text { Euterpe }\end{array}$ \\
\hline $\begin{array}{l}\text { Cruz Alta (3) } \\
28^{\circ} 37^{\prime} 35.94^{\prime \prime} \mathrm{S} \\
53^{\circ} 37^{\prime} 57.66^{\prime \prime} \mathrm{W}\end{array}$ & Summer 2012 & $\begin{array}{l}\text { PP: Brassica }(56.6 \%) \\
\text { PA: Eucalyptus }(41.8 \%)\end{array}$ & $\begin{array}{l}\text { Heterofloral sample with primary } \\
\text { contribution of Brassica and } \\
\text { Eucalyptus }\end{array}$ \\
\hline $\begin{array}{l}\text { Jacutinga } \\
27^{\circ} 43^{\prime} 38.3^{\prime \prime} \mathrm{S} \\
52^{\circ} 32^{\prime} 15.3^{\prime \prime} \mathrm{W}\end{array}$ & Summer 2012 & $\begin{array}{l}\text { PA: Melastomataceae }(40.2 \%) \text {; Myrcia }(32.7 \%) \text {; } \\
\quad \text { Piper }(22.9 \%)\end{array}$ & $\begin{array}{l}\text { Heterofloral sample with primary } \\
\text { contribution of Melastomataceae, } \\
\text { Myrcia and Piper }\end{array}$ \\
\hline $\begin{array}{l}\text { Cambará do Sul (1) } \\
28^{\circ} 54^{\prime} 45.06^{\prime \prime} \mathrm{S} \\
50^{\circ} 04^{\prime} 58.45^{\prime \prime} \mathrm{W}\end{array}$ & Spring 2012 & $\begin{array}{l}\text { PP: Mimosa scabrella }(81.6 \%) \text {; } \\
\text { PI: Poaceae }(5.8 \%) \text {; undetermined }(3.7 \%)\end{array}$ & Monofloral sample of Mimosa scabrella \\
\hline $\begin{array}{l}\text { Cambará do Sul (2) } \\
28^{\circ} 54^{\prime} 45.06^{\prime \prime} \mathrm{S} \\
50^{\circ} 04^{\prime} 58.45^{\prime \prime} \mathrm{W}\end{array}$ & Spring 2012 & PP: Mimosa scabrella (94.8\%) & Monofloral sample of Mimosa scabrella \\
\hline $\begin{array}{l}\text { Cambará do Sul (3) } \\
28^{\circ} 54^{\prime} 45.06^{\prime \prime} \mathrm{S} \\
50^{\circ} 04^{\prime} 58.45^{\prime \prime} \mathrm{W}\end{array}$ & Spring 2012 & $\begin{array}{l}\text { PP: Mimosa scabrella }(86 \%) \\
\text { PI: Ilex }(7.1 \%) ; \text { Baccharis }(4.7 \%)\end{array}$ & Monofloral sample of Mimosa scabrella \\
\hline $\begin{array}{l}\text { Cambará do Sul (4) } \\
28^{\circ} 54^{\prime} 45.06^{\prime \prime} \mathrm{S} \\
50^{\circ} 04^{\prime} 58.45^{\prime \prime} \mathrm{W}\end{array}$ & Spring 2012 & PP: Mimosa scabrella (99.2\%) & Monofloral sample of Mimosa scabrella \\
\hline $\begin{array}{l}\text { Cambará do Sul (5) } \\
28^{\circ} 54^{\prime} 45.06^{\prime \prime} \mathrm{S} \\
50^{\circ} 04^{\prime} 58.45^{\prime \prime} \mathrm{W}\end{array}$ & Spring 2012 & $\begin{array}{l}\text { PP: Ilex }(71.8 \%) \text {; PA: Asteraceae }(20.5 \%) \text {; } \\
\text { PI: Podocarpus }(7.3 \%) \text {; Protium }(3.8 \%)\end{array}$ & $\begin{array}{l}\text { Heterofloral sample with primary } \\
\text { contribution of Ilex and Asteraceae }\end{array}$ \\
\hline $\begin{array}{l}\text { Cambará do Sul (6) } \\
28^{\circ} 54^{\prime} 45.06^{\prime \prime} \mathrm{S} \\
50^{\circ} 04^{\prime} 58.45^{\prime \prime} \mathrm{W}\end{array}$ & Spring 2012 & $\begin{array}{l}\text { PP: Eucalyptus }(75.7 \%) \text {; } \\
\text { PI: Lamanonia }(15 \%) \text {; Ilex }(4.5 \%) \text {; } \\
\quad \text { Asteraceae }(3 \%)\end{array}$ & Monofloral sample of Eucalyptus \\
\hline $\begin{array}{l}\text { Cambará do Sul (7) } \\
28^{\circ} 54^{\prime} 45.06^{\prime \prime} \mathrm{S} \\
50^{\circ} 04^{\prime} 58.45^{\prime \prime} \mathrm{W}\end{array}$ & Spring 2012 & $\begin{array}{l}\text { PP: Eucalyptus }(69.8 \%) \text {; } \\
\text { PA: Eupatorium }(29.2 \%)\end{array}$ & $\begin{array}{l}\text { Heterofloral sample with primary } \\
\text { contribution of Eucalyptus and } \\
\text { Eupatorium }\end{array}$ \\
\hline $\begin{array}{l}\text { Cambará do Sul (8) } \\
28^{\circ} 54^{\prime} 45.06^{\prime \prime} \mathrm{S} \\
50^{\circ} 04^{\prime} 58.45^{\prime \prime} \mathrm{W}\end{array}$ & Spring 2012 & $\begin{array}{l}\text { PA: Mimosa scabrella }(43.7 \%) \text {; Ilex }(42.0 \%) \\
\text { PI: Eupatorium }(6.4 \%) ;\end{array}$ & $\begin{array}{l}\text { Heterofloral sample with } \\
\text { primary contribution of Mimosa } \\
\text { scabrella and Ilex }\end{array}$ \\
\hline
\end{tabular}


Table III. (Continued).

\begin{tabular}{|c|c|c|c|}
\hline $\begin{array}{l}\text { Municipalities/GPS } \\
\text { coordinates }\end{array}$ & $\begin{array}{l}\text { Collection } \\
\text { period }\end{array}$ & Palynological evaluation & Predominant botanical origin \\
\hline $\begin{array}{l}\text { Eldorado do Sul } \\
\text { samples (1-25) } \\
30^{\circ} 4^{\prime} 54.05^{\prime \prime} \mathrm{S} \\
51^{\circ} 39^{\prime} 55.81^{\prime \prime} \mathrm{W}\end{array}$ & Winter 2014 & $\begin{array}{l}\text { PP: Eucalyptus (86-100\%), without any accessory } \\
\text { pollen type }\end{array}$ & 25 monofloral samples of Eucalyptus \\
\hline $\begin{array}{l}\text { Eldorado do Sul } \\
\text { samples (26-27) } \\
30^{\circ} 4^{\prime} 54.05^{\prime \prime} \mathrm{S} \\
51^{\circ} 39^{\prime} 55.81^{\prime \prime} \mathrm{W}\end{array}$ & Winter 2014 & $\begin{array}{l}\text { PP: } \text { Myrcia }(78.8-88 \%) \text {, without any accessory } \\
\text { pollen type }\end{array}$ & Two monofloral samples of Myrcia \\
\hline $\begin{array}{l}\text { Eldorado do Sul } \\
\text { samples }(28-31) \\
30^{\circ} 4^{\prime} 54.05^{\prime \prime} \mathrm{S} \\
51^{\circ} 39^{\prime} 55.81^{\prime \prime} \mathrm{W}\end{array}$ & Winter 2014 & $\begin{array}{l}\text { Eucalyptus }(18.6-63.7 \%), \text { Myrcia }(31.1-88 \%), \text { Zea } \\
\text { mays, }(3.1-34.4 \%)\end{array}$ & $\begin{array}{l}\text { Four heterofloral samples with primary } \\
\text { contribution of Eucalyptus, Myrcia } \\
\text { and Zea mays }\end{array}$ \\
\hline
\end{tabular}

Thirty-one samples were obtained in the Eldorado do Sul municipality. The monofloral samples consisted of Eucalyptus in 25 samples and Myrcia in two samples. Heterofloral pollen batches were represented by these pollen types and, in addition, by Poaceae and Zea mays L. pollen grains.

\section{Discussion}

Although the southern Brazilian region shows a strong variety of vegetation (Veloso 1962; Rizzini 1997), some pollen types indicate that certain local plant taxa are particularly visited by the bees to collect and harvest pollen grains. Barth (2004) highlighted that analyses of bee pollen loads in the southern region have not been frequent. Recently, Freitas et al. (2013) examined the composition of some monofloral pollen batches obtained in the States of Santa Catarina and Rio Grande do Sul.

\section{Paraná}

Three monofloral samples of Piptocarpha, Machaerium and Eucalyptus pollen types occurred. The genus Piptocarpha is characteristic of Paraná; these trees occur in both the ombrophilous forest and in disturbed areas of secondary forests (Grokoviski et al. 2009). The Machaerium pollen type was also observed in honey samples from Paraná also by Borsato et al. (2014) and in samples from several environments by Bortoluzzi et al. (2004); these plants are widely used for the restoration of degraded areas (Lorenzi 1992, 1998).

Several species of Eucalyptus are cultivated in Brazil, mainly in the south and southeast regions. They have been introduced to Brazil since the beginning of the nineteenth century. This pollen type was observed in several honey samples from southern
Brazil (Barth 1989) and is frequently visited by Apis mellifera, for which it serves as a pollen and protein resource (Pacheco et al. 1986).

\section{Santa Catarina}

No monofloral samples were obtained. Heterogeneity of pollen batches was found to be shown by the frequent pollen types of Brassica, Celtis, Eucalyptus, Eupatorium, Euterpe, Ilex, Montanoa, Anacardiaceae, Asteraceae, Melastomataceae and Poaceae. Freitas et al. (2013) recognised a monofloral pollen batch of a Caesalpiniaceae and another of the Mimosa caesalpiniaefolia Benth. pollen type in this state. The heterofloral samples also presented Asteraceae and Brassica pollen types, as in one sample from Içara (Santa Catarina State).

The Euterpe pollen type and some genera of Asteraceae (Eupatorium, Senecio, Montanoa) were representative of the Santa Catarina samples. Euterpe palm trees are of significant distribution in the ombrophilous forest (Raupp et al. 2009), but tree specimens were less representative in these samples. Asteraceae are particularly well represented in savannas and grasslands and, comparatively, not very significant in humid tropical forest lowlands (Jeffrey 2006). The pollen types Eupatorium (herbaceous to arboreal), Senecio (herbaceous) and Montanoa (shrub) found in the Santa Catarina samples may be indicating proximity to a forest region (Liebsch \& Acra 2004), as they were generally characterised as pioneers genera.

Several pollen types were of low frequency in the samples analysed. These pollen types are useful for characterising the phytogeographical region surrounding the apiaries in each municipality. A mixture of ombrophilous forest (Machaerium, Phoradendron, Piper, Ilex and Psychotria) with field vegetation (Poaceae, Asteraceae) and crop elements (Eucalyptus and Brassica napus) could be observed. The bees, as well 
as the foraging plants (Veloso 1962; Rizzini 1997), are adapted to a cold climate in this region.

\section{Rio Grande do Sul}

The 35 monofloral samples consisted primarily of pollen grains of Eucalyptus, Brassica, Myrcia, Machaerium, Andira, Piptocarpha and the Mimosa scabrella pollen type. In addition, pollen types of Eupatorium and Dalbergia as well as of Zea mays, Ilex, Euterpe, Asteraceae, Melastomataceae and Poaceae also occurred at lower concentrations.

Three of four dried pollen batches of the São Gabriel municipality presented Brassica and Eucalyptus pollen grains at high concentrations; one sample (of Brassica) was considered monofloral. Large areas of Rio Grande do Sul are covered by crops such as Brassica napus ('canola') (Rosa et al. 2010, 2011) that are widely visited by Apis mellifera. All the samples from the Cruz Alta municipally contained high concentrations of Eucalyptus and Brassica pollen grains; one sample was considered monofloral of Eucalyptus. Cambará do Sul municipality contributed eight samples, four of them monofloral of the Mimosa scabrella pollen type, one of Eucalyptus.

Mimosa scabrella pollen was frequently found in honey and pollen samples from southern Brazil (Barth 1989; Freitas et al. 2013; Borsato et al. 2014). This species is a pioneer, mainly related to secondary vegetation; it is very tolerant of various soil conditions (Machado et al. 2008). Monofloral batches of $M$. scabrella have been analysed by Freitas et al. (2013) in one sample from São Paulo. Ramalho et al. (1990) highlighted that in the Neotropical region, the $M$. scabrella pollen type is commonly collected by Apis mellifera.

One sample from Ijuí presented a monofloral batch of Andira pollen type. Species of this genus are not frequent in pollen samples from southern Brazil. They were commonly found in open land areas and in secondary forests; this information indicates a preference for wet soils (Lorenzi 2002).

Thirty-one samples obtained from several apiaries of the Eldorado do Sul municipality were predominantly monofloral: 25 of Eucalyptus, two Myrcia. The Myrtaceae family is well represented in the ombrophilous forest (Grings \& Brack 2009). The high frequency of the Eucalyptus pollen type may be associated with the large-scale replacement of native vegetation by other forms of land occupation. Large areas of forests have been converted into food production areas, especially into grain agriculture, and/ or have been planted with Pinus and Eucalyptus species (Pinha \& Siminski 2011).

\section{Conclusion}

The pollen analysis of the 49 pollen loads obtained in the state of Rio Grande do Sul showed how significant the information is to be gained from the study of a major number of colonies in different municipalities. If sufficient source material is available, the bees specialise on a given plant species: e.g. in our study, Eucalyptus, followed by Brassica, Mimosa scabrella and Myrcia. Further studies can potentially yield better resolution through field observation and plant species identification based on the pollen morphology of monofloral bee products. The heterofloral pollen batches represent the heterogeneity of the local beeresource flora; they also indicate the context within which a uniform product can be obtained for consumption. However, a major incentive is needed to develop and implement a comprehensive and detailed botanical certification programme to increase the commercial value of bee pollen products.

\section{Acknowledgements}

The authors thank all the beekeepers who provided samples.

\section{Funding}

The authors are grateful for financial support from Fundação de Amparo à Pesquisa do Estado de São Paulo (FAPESP) [grant number 2011/51826-0] to LBAM and from Conselho Nacional de Desenvolvimento Científico e Tecnológico (CNPq) [grant number 304067/2013-0] to OMB.

\section{Disclosure statement}

No potential conflict of interest was reported by the authors.

\section{References}

Almeida-Muradian LB, Pamplona LC, Coimbra S, Barth OM. 2005. Chemical composition and botanical evaluation of dried bee pollen pellets. Journal of Food and Composition Analysis 18: 105-111. doi:10.1016/j.jfca.2003.10.008.

Barreto LMRC, Funari SRC, Orsi RO. 2005. Composição e qualidade do pólen apícola proveniente de sete estados brasileiros e do Distrito Federal. Boletim da Indústria Animal 62: 167-175.

Barth OM. 1989. O pólen no mel brasileiro. Rio de Janeiro: Gráfica Luxor.

Barth OM. 2004. Melissopalynology in Brazil: A review of pollen analysis of honeys. propolis and pollen loads of bees. Scientia Agrícola 61: 342-350.

Barth OM, Freitas ASF, Oliveira ES, Silva RA, Maester FM, Andrella RRS, Cardozo GMBQ. 2010. Evaluation of the botanical origin of commercial dry bee pollen load batches using pollen analysis: A proposal for technical standardization. Anais 
da Academia Brasileira de Ciências 82: 893-902. doi:10.1590/ S0001-37652010000400011.

Borsato DM, Farago PV, Luz CFP, De Alencar SM, De Almeida MM. 2014. Physicochemical quality, botanical origin and antioxidant properties of floral honeys from Campos Gerais region, Brazil. Interciência 39: 249-254.

Bortoluzzi RLC, Carvalho-Okano RM, Garcia FCP, Tozzi AMGA. 2004. Leguminosae, Papilionoideae no Parque Estadual do Rio Doce, Minas Gerais, Brasil. II: Árvores e arbustos escandentes. Acta Botânica Brasilica 18: 49-71.

Carmo MRB, Andrade ALP, Santos GASD, Assis MA. 2012. Análise estrutural em relictos de cerrado no Parque Estadual do Guartelá, Município de Tibagi, Estado do Paraná, Brasil. Ciência Florestal 22: 505-517. doi:10.5902/198050986618.

Falkenberg D, Simões T. 2011. Espécies de interesse apícola e sua fenologia de floração. In: Coradin L, Siminski A, Reis A, eds. Espécies nativas da flora brasileira de valor econômico atual ou potencial: Plantas para o futuro - Região Sul. Brasília: MMA.

Freitas AS, Arruda VAS, Almeida-Muradian LB, Barth OM. 2013. The botanical profiles of dried bee pollen loads collected by Apis mellifera (Linnæus) in Brazil. Sociobiology 60: 56-64. doi:10.13102/sociobiology.v60i1.56-64.

Gasper AL, Sevegnani L, Vibrans AC, Sobral M, Uhlmann A, Lingner DV, Rigon-Júnior MJ, Marcio Verdi M, Stival-Santos A, Dreveck S, Korte A. 2013. Inventário florístico florestal de Santa Catarina: Espécies da Floresta Ombrófila Mista. Rodriguésia 64: 201-210. doi:10.1590/S2175-78602013000200001.

Grings M, Brack P. 2009. Árvores da vegetação nativa de Nova Petrópolis, Rio Grande do Sul. Iheringia, Série Botânica 64: 5-22.

Grokoviski L, Cervi AC, Tardivo RC. 2009. O gênero Piptocarpha R.Br. (Asteraceae: Vernonieae) no Estado do Paraná, Brasil1. Acta Botânica Brasílica 23: 486-498. doi:10.1590/S010233062009000200020.

Jacobi US, Duarte CI, Gonçalves RS, Acunha JS, Hefler SM. 2013. Florística dos ecossistemas do Campus Carreiros, Rio Grande, Rio Grande do Sul, Brasil. Iheringia, Série Botânica 68: 73-89.

Jeffrey C. 2006. Compositae. Introduction with keys to tribes. In: Kadereit JW, Jeffrey C, eds. Baccharis sect. Caulopterae. The families and genera of vascular plants, Volume 8. Flowering plants: Eudicots: Asterales, 61-77. Berlin: Springer.

Liebsch D, Acra LA. 2004. Riqueza de espécies de sub-bosque de um fragmento de Floresta Ombrófila Mista em Tijucas do Sul, PR. Ciência Florestal 14: 67-76.

Lorenzi H. 1992. Árvores brasileiras: Manual de identificação e cultivo de plantas arbóreas do Brasil. Nova Odessa: Editora Plantarum.

Lorenzi H. 1998. Árvores brasileiras: Manual de identificação e cultivo de plantas arbóreas nativas do Brasil. Nova Odessa: Editora Plantarum.

Lorenzi H. 2002. Árvores brasileiras: Manual de identificação e cultivo de plantas arbóreas do Brasil. Nova Odessa: Instituto Plantarum.

Luz CFP, Bacha Junior GL, Fonseca RLS, Sousa PR. 2010. Comparative pollen preferences by africanized honeybees Apis mellifera L. of two colonies in Pará de Minas, Minas Gerais, Brazil. Anais da Academia Brasileira de Ciências 82: 293-304. doi:10.1590/S0001-37652010000200005.

Luz CFP, Barth OM. 2012. Pollen analysis of honey and beebread derived from Brazilian mangroves. Revista Brasileira de Botânica 35: 79-85.
Luz CFP, Thomé ML, Barth OM. 2007. Recursos tróficos de Apis mellifera L. (Hymenoptera, Apidae) na região de Morro Azul do Tinguá, Estado do Rio de Janeiro. Revista Brasileira de Botânica 30: 29-36.

Machado SA, Aguiar LP, Figueiredo Filho A, Koehler HS. 2008. Modelagem do volume do povoamento para Mimosa scabrella Benth. Na região metropolitana de Curitiba. Revista Árvore 32: 465-478. doi:10.1590/S010067622008000300009.

Marchini LC, Reis VDA, Moreti ACCC. 2006. Composição físico-química de amostras de pólen coletado por abelhas Africanizadas Apis mellifera (Hymenoptera: Apidae) em Piracicaba, Estado de São Paulo. Ciência Rural 36: 949-953. doi:10.1590/ S0103-84782006000300034.

Moreti ACCC, Marchini LC, Souza VC, Rodrigues RR. 2002. Atlas do pólen de plantas apícolas. Rio de Janeiro: Papel Virtual Editora.

Negrelle RAB, Silva SC. 1992. Fitossociologia de um trecho de floresta com Araucaria angustifolia (Bert.) O.Ktze. no município de Caçador Santa Catarina. Embrapa florestas. Boletim de pesquisa florestal Colombo 24/25: 37-54.

Pacheco IA, Kagevama PY, Wiendl FM, Berti Filho E. 1986. Estudo da dispersão do pólen de Eucalyptus saligna Smith por abelhas Apis mellifera L. utilizando-se o radiofósforo 32P. IPEF 34: 47-52.

Pinha PRS, Siminski A. 2011. A região Sul. In: Coradin L, Siminski A, Reis A, eds. Espécies nativas da flora brasileira de valor econômico atual ou potencial: Plantas para o Futuro Região Sul. Brasília: MMA.

Pirani JR, Cortopassi-Laurino M. 1993. Flores e abelhas em São Paulo. São Paulo: Edusp.

Ramalho M, Kleinert-Giovannini A, Imperatriz-Fonseca VL. 1990. Important bee plants for stingless bees (Melipona and Trigonini) and africanized honeybees (Apis mellifera) in Neotropical habitats: A review. Apidologie 21: 469-488. doi: 10.1051/apido:19900508.

Raupp SV, Brack P, Leite SLC. 2009. Aspectos demográficos de palmiteiro (Euterpe edulis Mart.) em uma área da Floresta Atlântica de Encosta, em Maquiné, Rio Grande do Sul. Iheringia, Série Botânica 64: 57-61.

Rizzini CT. 1997. Tratado de Fitogeografia do Brasil. Rio de Janeiro: Âmbito Cultural Edições.

Rosa AS, Blochtein B, Ferreira NR, Witter S. 2010. Apis mellifera (Hymenoptera: Apidae) as a potential Brassica napus pollinator (cv. Hyola 432) (Brassicaceae), in Southern Brazil. Brazilian Journal of Biology 70: 1075-1081. doi:10.1590/S151969842010000500024 .

Rosa AS, Blochtein B, Lima DK. 2011. Honey bee contribution to canola pollination in Southern Brazil. Scientia Agricola 68: 255-259. doi:10.1590/S0103-90162011000200018.

Roubik DW, Moreno JEP. 1991. Pollen and spores of Barro Colorado Island. Monographs in Systematic Botany. St. Louis, MO: Missouri Botanical Garden.

Santos FAR. 2011. Identificação botânica do pólen apícola. Magistra 23: 5-9.

Troppmair H. 1990. Perfil fitoecológico do estado do Paraná. Boletim de Geografia 8: 67-80.

Veloso H. 1962. Os grandes clímaces do Brasil - considerações sobre os tipos vegetativos da região Sul. Memórias do Instituto Oswaldo Cruz 60: 175-194. 